\title{
Responses to Chinese Rule in Xinjiang: Patterns of Cooperation and Opposition
}

\author{
By Dru C. Gladney (USA)
}

In the summer of 2002, both the United States and the United Nations supported China's claim that an organization known as the East Turkistan Islamic Movement (ETIM) should be recognized as an international terrorist organization. ${ }^{1}$ It is important to note, however, that China makes little distinction between separatists, terrorists, and civil rights activists - whether they are Uyghurs, Tibetans, Taiwanese, or Falun Gong Buddhists. One person's terrorist may be another's freedom fighter. Are the restive Uyghurs of Xinjiang terrorists, separatists, or freedom fighters? How can the incidents of recent years be seen in the context of the Chinese efforts to integrate the region in the course of two decades of the post-Deng reforms?

After denying the problem for decades and stressing instead China's "national unity," official reports and the state-run media began in early 2001 to detail terrorist activities in the regions officially known as the Xinjiang Uyghur Autonomous Region. ${ }^{2}$ Prior to the release of this document by the State Council, and the subsequent media reports, the term "Eastern Turkestan" was not allowed to be used in the official media, and anyone found using the term or referring to Xinjiang as Eastern Turkestan could be arrested, even though this is the term most often used outside China to refer to the region by Uyghurs and other Turkic-speaking people. In the northwestern Uyghur Autonomous Region of Xinjiang, China's State Council and the official media an on-going series of incidents of terrorism and separatism since the large riot in the Xinjiang town of Yining of February 1997, with multiple crackdowns and arrests that have rounded up thousands of terrorist suspects, large weapons caches, and printed documents allegedly outlining future public acts of violence. ${ }^{3}$

${ }^{1}$ Erik Eckholm, "U.S. Labeling of Group in China as Terrorist is Criticized"

The New York Times September 13, 2002, p. 1.

${ }^{2}$ Chinese State Council. White Paper on Xinjiang Uyghur Autonomous Region. Beijing, February 2002. (will need to check exact title and date). "China Also Harmed by Separatist-Minded Eastern Turkistan Terrorists," People's Daily, October 10, 2001.

${ }^{3}$ CNN News Service, Rym Brahimi, "Russia, China, and Central Asian Leaders Pledge to Fight Terrorism, Drug Smuggling”, 25 August 1999 (electronic format <www.uygur.org/enorg/wunn99/990825e.html>) 
Amnesty International has claimed that these round-ups have led to hurried public trials and immediate, summary executions of possibly thousands of locals. One estimate suggested that in a country known for its frequent executions, Xinjiang had the highest number, averaging 1.8 per week, most of them Uyghur. ${ }^{4}$ Troop movements to the area, related to the nationwide campaign against crime known as "Strike Hard" launched in 1998 that includes the call to erect a "great wall of steel" against separatists in Xinjiang, were reportedly the largest since the suppression of the large Akto insurrection in April 1990 (the first major uprising that initiated a series of unrelated and sporadic protests). ${ }^{5}$ Alleged incursions of Taliban fighters through the Wakhan corridor into China where Xinjiang shares a narrow border with Afghanistan have led to the area being swamped with Chinese security forces and large military exercises, beginning at least one month prior to the September $11^{\text {th }}$ attack. Under US and Chinese pressure, Pakistan returned one Uyghur activist to China, apprehended among hundreds of Taliban detainees, which follows a pattern of repatriations of suspected Uyghur separatists from Kazakstan, Kyrgyzstan, and Uzbekistan. ${ }^{6}$

International campaigns for Uyghur rights and possible independence have become increasingly vocal and well organized, especially on the internet. Repeated public appeals have been made to Abdulahat Abdurixit, the Uyghur People's Government Chairman of Xinjiang in Urumqi. International organizations are increasingly including Uyghur indigenous voices from the expatriate Uyghur community. Notably, the 1995 elected chair of the Unrepresented Nations and People's Organization (UNPO) based in the Hague is a Uyghur, Erkin Alptekin, son of the separatist leader, Isa Yusuf Alptekin, who is buried in Istanbul where there is a park dedicated to his memory. ${ }^{7}$ Supporting primarily an audience of mostly expatriate Uyghurs, there are at least 25 international organizations and web sites working for the independence of "Eastern Turkestan," and based in Amsterdam, Munich, Istanbul, Melbourne, Washington, DC and New York. Following 11 September 2001, the vast majority of these organiza-

\footnotetext{
${ }^{4}$ Amnesty International, People's Republic of China: Gross Violations of Human Rights in the Xinjiang Uighur Autonomous Region (London, 21 April 1999), p. 24.

${ }^{5}$ Hutzler, Charles, "Trade is China's Carrot to Muslim Separatists,"Wall Street Journal, September 21, 2001.

${ }^{6}$ Eckholm, Erik, Smith, Craig S., "Fearing Unrest, China Pressures Muslim Group," New York Times, October 5, 2001; Pun, Pamela, "Separatists Trained in Afghanistan, says Official," The Standard, posted at hkimail.singtao.com/inews/public/article_v.cfm?articleid=30156\&intcatid=2, October 22, 2001 .

${ }^{7}$ See writings by Isa Yusuf Alptekin's son, Erkin Alptekin, which also present alternative histories of the Uyghur from that of the Chinese state: Alptekin, Erkin, Uygur Tbrkleri [The Uygur Turks]. Istanbul: Bopazizi Yayэnlarэ, 1978; and 'Xinjiang a Time Bomb Waiting to Explode,' South ChinaMorning Post (Hong Kong), 29 May, 2002. For Alptekin's involvement with the Unrecognized Nations and Peoples Organization in The Hague, see their website: www.unpo.org/member/eturk.html.
} 
tions disclaimed any support for violence or terrorism, pressing for a peaceful resolution of on-going conflicts in the region. Nevertheless, the growing influence of "cyber-separatism" is of increasing concern to Chinese authorities seeking to convince the world that the Uyghurs do pose a real domestic and international terrorist threat.

The real question is, what changes in the region have the events of September $11^{\text {th }}$ wrought in terms of local response to Chinese rule? It is clear that the so-called separatist activities are not new and that China is taking advantage of the international war on terrorism to attempt to eradicate a domestic problem. The Istanbul-based groups have existed since the 1950s, the Central Asian Uyghurs under Soviet rule received tremendous support in their antiChina rhetoric regarding policies in Xinjiang, and the Uyghurs have been increasingly vocal since the independence of the Central Asian Republics in 1991 led many to hope for an independent Uyghuristan would have followed on the heels of the other newly independent -stans. Separatist actions have taken place on a small but regular basis since the expansion of market and trade policies in China, and with the opening of six overland gateways to Xinjiang in addition to the trans-Eurasian railway, and China's Western development campaign, there seems to be no chance of closing up shop. The Chinese government itself in a landmark 1999 white paper, admitted serious economic shortfalls in the region despite 50 years of state investment in the development of the region: "The Chinese government is well aware of the fact that...central and western China where most minority people live, lags far behind the eastern coastal areas in development." 8

In previous years, China denied any serious social or political problems in the region and followed the old Soviet "divide-and-rule" strategy which sought to limit all references to Turkestan or even Turkology that might link the Uyghurs, Kazakhhs, and other Turkic-speaking minorities to broader pan-Turkic movements. Yet certainly since early 2001, due to the desire to receive international support for its domestic war on terrorism, China's Foreign Ministry and the People's Daily have documented an on-going series of incidents of terrorism and separatism since the large riot in the Xinjiang town of Yining of February 1997, with multiple crackdowns and arrests that have rounded up thousands of terrorist suspects, large weapons caches, and printed documents allegedly out-

\footnotetext{
${ }^{8}$ Information Office of the State Council of the People's Republic of China "National Minority Policies and Its Practice in China", 1999, p. 50. See also the Law of the People's Republic of China on Regional National Autonomy (1984), with full text of White Paper on Minority Policies, September 28, 1999, at www.China.org.cn. For poverty in the region specifically among the Uyghur, see Gilley, Bruce, "'Uyghurs need not Apply," Far Eastern Economic Review, August 28, 2001
} 
lining future public acts of violence. In June 2002, under US and Chinese pressure, Pakistan returned one Uyghur activist to China, apprehended among hundreds of Taliban detainees, which follows a pattern of repatriations of suspected Uyghur separatists in Kazakhhstan, Kyrgyzstan, and Uzbekistan. This detainee was supposedly one of several hundred Uyghurs arrested fighting with the Taliban, with up to 6 Uyghurs placed in the Guantanomo Bay detention facility. ${ }^{9}$ Clearly, domestic responses to Chinese rule have changed dramatically in the last 20 years for there to be large groups of Uyghur militant Muslims fighting abroad, and for the Chinese government to publicize separatist actions inside and outside the region, launching large-scale suppressions of potential terrorists. Nevertheless, despite China's increasing crackdowns, fewer reports of civil unrest or terrorist acts have been reported since the late 1990s. This suggests a changing pattern of opposition to Chinese rule in the region.

\section{LOYALTY, VOICE, Or EXIT?}

Taking inspiration from the Princeton economist Albert O. Hirschman's classic model regarding participation in organizations and states, ${ }^{10}$ one might locate certain patterns of response to Chinese rule since 1978. Although Hirschman's theory of "Exit, Voice, or Loyalty" was applied to institutions and states in decline, and this volume has argued that China's presence in Xinjiang has anything but declined, nevertheless it could be argued that for many Uyghur these are the main options available to them in a region where their own population numbers and influence have declined precipitously over the last 50 years of Chinese rule. It was clear that the post-Cultural Revolution period in the region was welcomed by most Xinjiang residents due to the harsh treatment of minorities and religious practitioners between 1966 and 1976. Indeed, many Muslims point to the 20 years of discrimination against religious practice since the initiation of the Religious System Reform Campaign in 1958, which led throughout the country to the further consolidation and restriction of religious practice. ${ }^{11}$ With the Deng liberalization of the marketplace, cultural and religious practice also flourished, leading to widespread mosque-building and the

\footnotetext{
9 "Uyghur Separatist Sentenced to Death," Reuters, October 18, 2001; Smith, Craig S., "Fearing Unrest, China Pressures Muslim Group," New York Times, October 5, 2001; Pun, Pamela, "Separatists Trained in Afghanistan, says Official," The Standard, posted at hk-imail.singtao.com/inews/public/ article v.cfm?articleid=30156\&intcatid=2, October 22, 2001

${ }^{10}$ Albert O. Hirschman, Exit, Voice, or Loyalty; Response to Decline in Firms, Organizations, and States. Cambridge: Harvard University Press, 1972.

${ }^{11}$ See Dru C. Gladney, Muslim Chinese: Ethnic Nationalism in the People's Republic Cambridge: Harvard University Press, 1996, pp. 122-30.
} 
revival of religious education in the region. It was during this period that most of the mosques in the region were built or reopened, Islamic training of young Imams permitted, and pilgrimages to Mecca resumed. Indeed, there are many residents of Xinjiang, Uyghurs included, who continue to strongly support the Deng Xiaoping reforms as they have been continued under Jiang Zemin and now Hu Juntao. As loyal citizens, they see the dramatic progress made since the end of the Cultural Revolution and generally share in the government's vision of a modernized, developed Xinjiang region. Working not only in the state sector as cadres, teachers, production corps farmers, and factory workers, but also in the growing private sector in private and semi-private small businesses, these supporters of the state's development program are generally quite unwilling to listen to any criticism of state policies, especially from outsiders or disgruntled minorities. Given the lack of public polling or uncensored media in the region, it is difficult to ascertain if these supporters are a silent majority or a tiny minority, speaking out in support of state policies because it serves their interest. Nevertheless, the Deng reform era in general can be characterized as a period of heightened loyalty to the state and new-found optimism after the previous 20 years of internal chaos and repression, similar in many respects to the period of relative loyalty when Xinjiang was first brought into the PRC and established as an Autonomous Region.

However, in the late 1980s and mid-1990s, this period of "loyalty" gave way to increasing expressions of "voice", not only among Uyghur but also among a wide cross-section of local residents that felt the northwest was not keeping pace with the rapid development of the rest of the country. Many Uyghurs were particularly disappointed that the independence of the former Soviet Central Asian Republics in 1991 did not lead to independence or at least increased autonomy in their own Autonomous Region. Throughout the early and mid1990s, increasing expressions of "voice" demonstrated these concerns from university protests to greater ethnic and civil unrest. Whether there were smaller, unreported incidents in the past, the mid-1990s witnessed an number of public expressions of dissent and dissatisfaction with state policies in the region.

The 1990s period of voiced opposition began with the report of a major uprising in Akto County (near Kashgar) in April 1990, that official reports stated involved and "armed counter-revolutionary rebellion" suppressed by the People's Liberation Army that led to twenty-two deaths. ${ }^{12}$ In 1995, Chinese People's

\footnotetext{
${ }^{12}$ See discussions of this event which had only sketchy reports by Mackerras, Colin. The New Cambridge Handbook of Contemporary China. 2001. p. 38; and Michael Dillon. Xinjiang: Ethnicity, Separatism and Control in Chinese Central Asia. 1995. p. 26.
} 
Police reported finding a large weapons cache, and in May 1996, a Xinjiang People's Political Consultative Conference official was assassinated, all later attributed to "East Turkestan" terrorists. ${ }^{13}$

In the Spring of 1996, the Xinjiang Daily reported five serious social eruptions in the region since February 1996, with a crackdown that rounded up 2,773 terrorist suspects, 6,000 lbs of explosives, and 31,000 rounds of ammunition. Overseas Uyghur groups claimed that over 10,000 were arrested in the roundup, with over 1,000 killed. ${ }^{14}$ The largest protest from 2 to 8 February 1996, was sparked by a Chinese raid on an evening Mashrap cultural meeting, where young Uighur men and women gather for prayer, singing of religious and folk songs, and feasting. ${ }^{15}$ Protests against the arrests made during the meeting led to 120 deaths and over 2,500 arrests. Immediately following the uprising and crackdown in Yining, on February $25^{\text {th }}$, the day of Deng Xiaoping's memorial speech, in a well-coordinated operation, three bombs exploded simultaneously on three buses in downtown Urumqi leading to 20 civilian deaths and scores of injured (including some Uyghurs), with the subsequent execution of eight Uighurs allegedly responsible for the bombings. ${ }^{16}$

Later that spring, the violence came to Beijing when on March 7 and then again on March 8, two separate bombs exploded on public buses. The first bomb in Xidan claimed three lives with ten injured, while the second bomb killed two. The bombs were timed to take place during the Chinese National Peoples Congress and were widely attributed to Uyghur separatists, though this has never been independently verified and no group has ever claimed responsibility. ${ }^{17}$ On 29 May 1996 the pro-government mullah of Kashgar's Idgah mosque, Arunkhanji, and his son were stabbed by knife-wielding Uyghur militants, on 27 May there was another attack on a senior government official, and in Sep-

\footnotetext{
${ }^{13}$ Reported in McNeal, Dewardic L. "China's Relations with Central Asian States and Problems with Terrorism.” US Department of State, Congressional Research Service Report, 2001. http://fpc.state.gov/documents/ organization/7945.pdf.

${ }^{14}$ Xinjiang Daily, April 9, 1997 from People's Republic of China: Gross Violation of Human Rights in the Xinjiang Uyghur Autonomous Region, Amnesty International, 1999; Reuters, Beijing, June 26, 1997, citing the Xinjiang Daily of July 21, 1997

${ }^{15}$ See Ildiko Beller-Hann, "Making the Oil Fragrant: Dealings with the Supernatural Among the Uyghurs in Xinjiang." Asian Ethnicity 2001, 2.1. pp. 9-23; see also Nathan Light's dissertation, Slippery Paths: The Performance and Canonization of Turkic Literature and Uyghur Muqam Song in Islam and Modernity, Indiana University, Bloomington, 1998, as well as his very informative webpage on Uyghur and Turkic culture and art, http:// www.utoledo.edu/ nlight/mainpage.htm.

${ }^{16} \mathrm{McNeal}$, op. cit.

${ }^{17}$ See “A Bomb in Beijing,” The Economist, March 13, 1997; Tyler, Patrick E., "Chinese Muslims Recount Their Days of Terror," New York Times, Sunday, November 10, 1996; p.3. Note that many Uyghurs in the diaspora believe that the bombs were set by Chinese authorities in order to justify a crackdown on Uyghurs in Xinjiang.
} 
tember of the same year six Uyghur government officials were killed by other Uyghurs in Yecheng.

The Yining uprising on 7 February 1997, and the subsequent bombings in Urumqi and Beijing, were heavily covered by the world's media. ${ }^{18}$ This distinguishes the late 1990s events from on-going problems in the region in the mid1980s that met with little media coverage.

In the late 1990s, the government responded with a host of arrests and new policy announcements. In Spring 1998, the National Peoples Congress passed a New Criminal Law that redefined "counter-revolutionary" crimes to be "crimes against the state", liable to severe prison terms and even execution. Included in "crimes against the state" were any actions considered to involve "ethnic discrimination" or "stirring up anti-ethnic sentiment."19 Many human rights activists have argued that this is a thinly veiled attempt to criminalize "political" actions and to make them appear as illegal as traffic violations, supporting China's claims that it holds "no political prisoners". Since any minority activity could be regarded as stirring "anti-ethnic feeling", many ethnic activists are concerned that the New Criminal Law will be easily turned against them.

The "Strike Hard Campaign", launched in Beijing in April 1997 was originally intended to clamp down on crime and corruption, and included severe restrictions on religious practice. ${ }^{20}$ These campaigns, according to an April 1999 Amnesty International report, have led to 210 capital sentences and 190 executions of Uyghur since 1997. ${ }^{21}$

The 1997 riot in Xining described above marked the apex of rioting and civil unrest among the Uyghur. After 1997 there was a marked decline in Xinjiang civil unrest and so-called separatist events, perhaps because of the government's harsh crackdown and arrest of prominent Uyghur activists. On 11 August 1999, Rebiya Kadeer, a well known Uyghur business woman once a delegate to the 1995 Beijing International Women's Conference, who was scheduled to meet with a United States Congressional Research Service delegation to the region, was arrested for "revealing state secrets." 22 Human rights activists claim that she was merely handing over Xinjiang news items previously published in the official news media to be taken back to her husband, currently living in exile in

\footnotetext{
18 "China Fears for its Wild West," The Economist, November 13, 1997.

${ }^{19}$ Amnesty International, op.cit., p. 21.

${ }^{20}$ Reuters, Beijing, June 26, 1997, citing the Xinjiang Daily of July 21, 1997; See Becquelin, Nicolas, "Xinjiang in the Nineties," The China Journal, No.44, July 2001.

${ }^{21}$ Amnesty International, Op. cit..

${ }^{22}$ Wall Street Journal, Ian Johnson, "China Arrests Noted Businesswoman in Crackdown in Muslim Region", 18 August 1999
} 
Washington, D.C. After reviewing her case, Amnesty International concluded that there was not enough evidence to detain her and launched an international campaign in the spring of 2002, designating her as their detainee of the month in hopes of winning her release. ${ }^{23}$

Despite on-going tensions and frequent reports of isolated terrorist acts, there has been no evidence that any of these actions have been aimed at disrupting the economic development of the region. Most confirmed incidents have been directed against Han Chinese security forces, recent Han Chinese йmigrŭs to the region, and even Uyghur Muslims perceived to be too closely collaborating with the Chinese Government. ${ }^{24}$ Most analysts agree that China is not vulnerable to the same ethnic separatism that split the former Soviet Union. But few doubt that should China fall apart, it would divide, like the USSR, along centuries old ethnic, linguistic, regional, and cultural fault lines. ${ }^{25}$ If China did fall apart, Xinjiang would split in a way that, according to Anwar Yusuf, President of the Eastern Turkistan National Freedom Center in Washington DC, "would make Kosovo look like a birthday party". It should be noted that despite the fear of widespread civil disorder, Mr Yusuf indicated that the Eastern Turkistan National Freedom Center continued to support a free and independent Xinjiang. ${ }^{26}$ On 4 June 1999 Mr Yusuf met with President Clinton to press for fuller support for the Uyghur cause. ${ }^{27}$ Subsequent Uyghur organizations have sought to pressure the Bush administration with varying degrees of success. Now many fear that with the U.S and China cooperating on a war on terrorism, there is no hope for U.S. support of Uyghur human rights' issues.

Since the high-point of the late 1990s expressions of voice and ethnic violence, there has been a gradual decline in the scale and number of incidents. Documented separatist and violent incidents in Xinjiang have dropped off dramatically since the late 1990s. Philip Pan reported in a July 14, 2002 Washington Post interview that local Xinjiang security officials were only able to cite three relatively small occurrences. ${ }^{28}$ Interestingly, few have noted that despite

\footnotetext{
${ }^{23}$ See article, “Amnesty International Women's Rights Action 2000 Women's Rights are Human Rights The Struggle Persists - CHINAArbitrary Detention of Rebiya Kadeer - a women's human rights defender and prisoner of conscience" AI Index: ASA 17/04/00.

http://web.amnesty.org/802568F7005C4453/0/08216A2C1385F107802568790040 AB7 1?Open

${ }^{24}$ Two exceptions include a reported derailment of a Xinjiang train due to a bombing on February 12, 1997, and an attack on a power station in Hejing on July 10, 1999 (unpublished Rand Report). These incidents, and the Beijing and Urumqi bus bombings of 1997, represent the only examples of well-organized terrorist activities directed against civilians.

${ }^{25}$ Dru C. Gladney, “China’s Ethnic Reawakening”, Asia Pacific Issues, No. 18 (1995), pp. 1-8

${ }^{26}$ Anwar Yusuf, President of the Eastern Turkistan National Freedom Center, Washington DC. Personal interview, 14 April 1999

${ }^{27}$ Turkistan News \& Information Network, "Press Release”, 8 June 1999

${ }^{28}$ Philip Pan "In China's West, Ethnic Strife Becomes 'Terrorism"”'Washington Post July 14, 2002: A4.
} 
many incidents of ethnic and civil unrest in the region, not one significant terrorist attack against any strategic infrastructural target (oil refinery, pipeline, railroad, dam, or bridge) has ever been documented, nor have any local or international incidents been positively identified with any international Uyghur or Islamic organization. In addition, visitors to the region have increasingly reported a sense of disillusionment and disappointment among activists. One acquaintance mentioned to this author in late August 2001, "We've given up on independence, we just want to immigrate." Loyalty and voice, for many young Uyghur, have turned to exit.

\section{CYBER-SEPARATISM: VIRTUAL VOICES IN THE UYGHUR OPPOSITION}

Though silenced within China, Uyghur voices can still be heard virtually, on the internet. Perhaps due to Chinese restrictions on public protest and a state-controlled media, or the deleterious effect of a war on domestic terrorism that this paper has documented began in the late 1990s, very few Uyghur voices can be heard today in the region critical of Chinese policies, at least not public ones. Interestingly, only by exercising Hirschman's alternative possibility of "exit" can Uyghur oppositional voices continue to be heard. International campaigns for Uyghur rights and possible independence have become increasingly vocal and well organized, especially on the internet. Supporting primarily an audience of approximately over 500,000 expatriate Uyghurs (yet few Uyghurs in Central Asia and China have access to these internet sites) there are at least 25 international organizations and web sites working for the independence of "Eastern Turkestan," and based in Amsterdam, Munich, Istanbul, Melbourne, Washington, DC and New York. ${ }^{29}$

Although the United Nations and the United States government have agreed with China that at least one international organization, ETIM, is a Uyghur-sponsored terrorist organization, the vast majority of the Eastern Turkestan independence and information organizations disclaim violence. Supported largely by Uyghur йmigrŭ's who left China prior to the Communist takeover in 1949, these

${ }^{29}$ Estimates differ widely on the number of Uyghurs living outside of China in the diaspora. Uyghurs in Central Asia are not always well-represented in the State censuses, particularly since 1991. Shichor estimates approximately 500,000 living abroad, about 5-6\% of the total world Uyghur population, see Yitzhak Shichor, "Virtual Transnationalism: Uygur Communities in Europe and the Quest for Eastern Turkestan Independence." Unpublished paper, 2002. Shichor notes that as in many statistical matters, Uyghur websites differ dramatically on the official Uyghur population numbers, from up to 25 million Uyghur inside Xinjiang, to up to 10 million in the diaspora, see, for example, www.Uyghur.org, the site supported by Anwar Yusuf, President of the Eastern Turkistan National Freedom Center in Washington, D.C. 
organizations maintain a plethora of websites and activities that take a primarily negative view of Chinese policies in the region. Although not all organizations advocate independence or separatism, the vast majority of them do press for radical change in the region, detailing not only human rights violations, but environmental degradation, economic imbalances and alternative histories of the region. In general, these websites can be divided roughly into those that are mainly information-based and others that are politically active advocacy sites. Nevertheless, whether informational or advocacy, nearly all of them are critical of Chinese policies in Xinjiang. ${ }^{30}$

It is difficult to assess who the audience is for these websites, as they are all blocked in China, and mostly inaccessible in Central Asia due to either inadequate internet access or the high costs of getting on the net. Many Uyghurs I have talked with in China and in Central Asia have never heard of most of these sites. Interestingly, government officials in Xinjiang interested in the information provided on these sites also have said they do not have access. It is clear that Uyghurs in the Western diaspora, particularly in Europe, Turkey, the United States, Canada, and Australia are frequent readers and contributors to these sites. In addition, events in the region since September 11 have led an increasing number of journalists and interested observers of the region to begin visiting the sites more regularly. In terms of content, it is interesting to note that a cursory monitoring of these sites reveals very little that can be associated with militant or radical Islam, and almost no calls for an Islamic "Jihad" against the Chinese state. Most of the issues as noted above involve documenting the plight and history of the Uyghurs under Chinese rule in Xinjiang as opposed to their glorious, independent past and long history in the region. It is also important to note that few Chinese inside or outside of China have visited these sites so that they are quite unaware of these alternative histories. Although there are several sites available in Turkish and Uyghur, there is not one in Chinese. As such, like all

\footnotetext{
${ }^{30} \mathrm{Key}$ informational websites that mainly provide Uyghur and Xinjiang related news and analyses, include the Turkistan Newsletter maintained by Mehmet Tutuncu of SOTA, www.euronet.nl/users/sota/turkistan.html, the Open Society Institute's www.erasianet.org, The Uyghur Information Agency's www.uyghurinfo.com, www.wlc.org, and the virtual library of the Australian National University based "Eastern Turkestan WWW VL" www.ccs.uky.edu/ $\sim$ rakhim/et.html. Advocacy sites that promote support for Uyghur- and Xinjiang-related causes, include Free Eastern Turkestan initiated by Jack Churchward, www.caccp.org/et, the East Turkestan Information Center www.uygur.org, the Eastern Turkestan National Freedom Center www.uyghur.org, The Uyghur Human Rights Coalition www.uyghurs.org, and other more popular sites including www.taklamakan.org, www.ugyur.net, www.kivilcim.com, www.doguturkistan.net, www.turpan.com, www.afn.org, www.eastturkistan.com. As most of these sites are cross-linked, they often repeat and pass along information contained on other sites. For a survey of many of these websites, see Shichor, op. cit.. There are a host of Central Asia-related sites that increasingly contain information and discussion of events in Xinjiang, see Harvard's Forum for Central Aisan Studies, www.fas.harvard.edu/ centasia .
} 
internet groups, it is a self-selected audience and rarely reaches beyond those who already support and are interested in the agenda supported by the site. Financial support for these organizations and websites come mostly from private individuals, foundations, and subscriptions (though these are rare). While it has been reported that wealthy Uyghur patrons in Saudi Arabia and Turkey, who became successful running businesses after migrating to these countries in the 1940s, have strongly supported these organizations financially in the past, there is no publicly available information on these sources.

Although most of these websites have limited funding and circulation, they should not be dismissed as forming only a "virtual" community without any substantial impact on events within Xinjiang. Not only have these websites served as an important source of information not available in the official Chinese media, but some scholars have begun to argue that internet sites often help to sway public opinion by virtue of their widespread availability and alternative reporting of important events. ${ }^{31}$ While analysts are divided about the potency of the internet for swaying public opinion or influencing domestic events, there is an emerging consensus that it has clearly altered the way information is circulated and opinions are formed. Perhaps more importantly, scholars have concluded that the "virtual communities" formed by internet websites establish links and connections that can lead to broad social interactions and coalitions which have impacted political and socio-economic events. For example, it has been shown that social movements in East Timor, Aceh, Chechnya, and Bosnia have been given strong support through these internet communities, providing not only increased information but large financial transfers as well. ${ }^{32}$ While "cyberseparatism" would never be able on its own to unseat a local government, it is clear that it does link like-minded individuals and raise consciousness about issues that were often inaccessible to the general public. For an isolated region such as Xinjiang, and the widely dispersed Uyghur diaspora, the internet has dramatically altered the way the world sees the region and the Chinese state must respond to issues within it.

\footnotetext{
${ }^{31}$ For studies of the influence of internet in influencing wider public opinion in Asia, see a recent collection of essays in the Asian Journal of Social Science edited by Zaheer Baber in a special focus on "The Internet and Social Change in Asia and Beyond", Vol. 30, No 2, 2002.

32 See Derek Foster, 1997. "Community and Identity in the Electronic Village" in David Porter, editor. Internet Culture. New York: Routledge Press; Steven G. Jones, 1997. "The Internet and Its Social Landscape" in Steven G. Jones, editor. Virtual Culture: Identity and Community in Cybersociety. London, New Delhi: Sage; Tim Jordan, 1999. Cyberpower: The Culture and Politics of Cyberspace and the Internet. London and New York: Routlege; Douglas Rushkoff, 1994. Cyberia: Life in the Trenches of Hyperspace. New York: Harper Collins; and Mark A. Smith and Peter Kollock, editors. 1999. Communities in Cyberspace. London and New York: Routledge.
} 
It is clear that there are more than just internet organizations involved in separatist activities in and around Xinjiang. As noted above, the East Turkestan Islamic Movement (ETIM) was recognized by the United Nations in October 2002 as an international terrorist organization responsible for domestic and international terrorist acts, which China claimed included a bombing of the Chinese consulate in Istanbul, assassinations of Chinese officials in Bishkek, and Uighur officials in Kashgar thought to collaborate with Chinese officialdom. ${ }^{33}$

This designation, however, created a controversy in that China and the U.S. presented little public evidence to positively link the ETIM organization with the specific incidents described. ${ }^{34}$ In 2001, the US State Department released a report that documented several separatist and terrorist groups operating inside the region and abroad, militating for an independent Xinjiang. ${ }^{35}$ The list included "The United Revolutionary Front of Eastern Turkestan" whose leader Yusupbek (Modan) Mukhlisi claimes to have 30 armed units with " 20 million" Uyghurs primed for an uprising; the "Home of East Turkistan Youth," said to be linked to Hamas with a reported 2000 members, the "Free Turkistan Movement" whose leader Abdul Kasim is said to have led the 1990 Baren uprising discussed above; the Organization for the Liberation of Uighuristan" how leader Ashir Vakhidi is said to be committed to the fighting Chinese "occupation" of the "Uighur homeland;" and the so-called "Wolves of Lop Nor" who have claimed responsibility for various bombings and uprisings. The State Department report claims that all of these groups have tenuous links with al Qaeda, Taliban, the Hizb-ut-Tahrir ("Islamic Revival"), and the Tableeghi Jamaat. Many of these groups were listed in the Chinese report that came out in early 2002, but failed to mention ETIM. It came as some surprise, therefore, when at the conclusion of his August 2001 visit to Beijing, Deputy Secretary of State Richard Armitage identified ETIM as the leading Uyghur group to be targeted as an international terrorist group. ${ }^{36}$ The main issue for those critical of this designa-

${ }^{33}$ The East Turkestan Islamic Movement (ETIM) is known only as a shadowy group known only to be previously active in Afghanistan and founded in the mid-90s by Hassan Mashum. Mahsum had served three years in a labor camp in Xinjiang and who recruited other Uighurs, including his number three leader Rashid who was captured with the Taliban and returned to China in Spring 2001. See Hutzler, Charles, "China-Iraq Policy Is Risky For US" Asian Wall Street Journal, September 10, 2001.

${ }^{34}$ "China Also Harmed by Separatist-Minded Eastern Turkistan Terrorists," People's Daily, October 10, 2001; Eckholm, Erik, "U.S. Labeling of Group in China as Terrorist is Criticized," New York Times, September 13, 2002; Hutzler, Charles, “U.S. Gesture to China Raises Crackdown Fears” Wall Street Journal, September 13,2002.

${ }^{35}$ McNeal, Dewardic L. "China's Relations with Central Asian States and Problems with Terrorism." US Department of State, Congressional Research Service Report, 2001. See also Scott Fogden's excellent thesis, Writing Insecurity: The PRC's Push to Modernize China and the Politics of Uighur Identity. MscEcon Thesis, University of Wales, Aberystwyth, 2002

${ }^{36}$ Conclusion of China Visit Press Conference, Deputy Secretary of State Richard L. Armitage, Beijing, China, U.S. Department of State, August 26, 2002. 
tion, with so many identified groups, why was ETIM singled out, unless it was for the political purpose of strengthening US-China relations. The real issue for this paper, however, is that despite the designation of ETIM, there are active Uyghur-related terrorist groups which can be said to be supportive of terrorism, but have never been proved to be directly implicated in any specific incident.

Chinese authorities are clearly concerned that increasing international attention to the treatment of its minority and dissident peoples have put pressure on the region, with the US and many Western governments continuing to criticize China for not adhering to its commitments to signed international agreements and human rights. Last year China ratified the International Covenant on Economic, Social, and Cultural Rights. Article One of the covenant says: "All peoples have the right of self-determination. By virtue of that right they freely determine their political status and freely pursue their economic, social and cultural development." Article 2 reads: "All peoples may, for their own ends, freely dispose of their natural wealth and resources without prejudice to any obligations arising out of international economic co-operation, based upon the principle of mutual benefit, and international law. In no case may a people be deprived of its own means of subsistence." Although China continues to quibble with the definition of "people", it is clear that the agreements are pressuring China to answer criticisms by Mary Robinson and other high-ranking human rights advocates about its treatment of minority peoples. Clearly, with Xinjiang representing the last Muslim region under communism, large trade contracts with Middle Eastern Muslim nations, and 5 Muslim nations on its western borders, Chinese authorities have more to be concerned about than just international support for human rights.

China's Uyghur separatists are small in number, poorly equipped, loosely linked, and vastly out-gunned by the People's Liberation Army and People's Police. And note that though sometimes disgruntled about other rights' and mistreatment issues, China's nine other official Muslim minorities do not in general support Uyghur separatism. Rudelson and Jankowiak have noted the enmity between Uyghur and Hui (Tungan) in the region. Few Hui support an independent Xinjiang, and one million Kazakh in Xinjiang would have very little say in an independent "Uyghuristan". Local support for separatist activities, particularly in Xinjiang and other border regions, is ambivalent and ambiguous at best, given the economic disparity between these regions and their foreign neighbors, including Tadjikistan, Kygyzstan, Pakistan, and especially Afghanistan. Memories in the region are strong of mass starvation and widespread destruction dur- 
ing the Sino-Japanese and civil war in the first half of this century, including intra-Muslim and Muslim-Chinese bloody conflicts, not to mention the chaotic horrors of the Cultural Revolution. Many local activists are calling not for complete separatism or real independence, but generally express concerns over environmental degradation, anti-nuclear testing, religious freedom, over-taxation, and recently imposed limits on childbearing. Many ethnic leaders are simply calling for "real" autonomy according to Chinese law for the five Autonomous Regions that are each led by First Party Secretaries who are all Han Chinese controlled by Beijing. Freedom of Religion, protected by China's constitution, does not seem to be a key issue, as mosques are full in the region and pilgrimages to Mecca are often allowed for Uyghur and other Muslims (though recent visitors to the region report an increase in restrictions against mosque attendance by youth, students, and government officials). In addition, Islamic extremism does not as yet appear to have widespread appeal, especially among urban, educated Uyghur, as Lipman and Fuller have noted. However, the government has consistently rounded up any Uyghur suspected of being "too" religious, especially those identified as Sufis or the so-called Wahabbis (a euphemism in the region for strict Muslim, not an organized Islamic school). The admitted problem of Uyghur terrorism and dissent, even in the diaspora, is thus problematic for a government that wants to encourage integration and development in a region where the majority population are not only ethnically different, but also devoutly Muslim. How does a government integrate a strongly religious minority (be it Muslim, Tibetan, Christian, or Buddhist) into a MarxistCapitalist system?

\section{PROSPECTS FOR THE FUTURE: NEW MODELS FOR CHINA'S NEW REGION?}

To an extent never seen before, the continued incorporation of Xinjiang into China has become inexorable, and perhaps irreversible. The need for the oil and mineral resources of the region since China became an oil importing nation in 1993 means that Chinese influence will only grow. To be sure, the Uyghur are still oriented culturally and historically toward Central Asia in terms of religion, language, and ethnic custom, and interaction has increased in recent years due to the opening of the roads to Pakistan and Almaty. Certainly, panTurkism was appealing to some, but not all, Uyghurs during the early part of this century. Historical ties to Central Asia are strong. Yet separatist notions, given the current political incorporation of Xinjiang into China, while perhaps present, are not practicable. As noted above, this is predicated on the assump- 
tion that China as a nation holds together. If China should fail at the centre, the peripheries will certainly destabilize, with Xinjiang and Tibet having the strongest prospects for separation given the history of dissent and organized separatist activities in the region. It is important to note here that other border regions with large minority populations, such as Yunnan, Guizhou, Guangxi (with 16 million Zhuang), Hainan, and even the Ningxia Hui Autonomous Region, have not had any reported separatist or terrorist activities. Clearly, by its own admission, the problems in Xinjiang and the oppositional voices of mostly Uyghur groups must be addressed by the state.

The problems facing Xinjiang, however, are much greater than those of Tibet if it were to become independent. Not only is it more integrated into the rest of China, but the Uyghur part of the population is less than half of the total and primarily located in the south, where there is less industry and natural resources, except for oil. As noted above, however, unless significant investment is found, Tarim oil and energy resources will never be a viable source of independent wealth. Poor past relations between the three main Muslim groups, Uyghur, Kazakh, and Hui, suggest that conflicts among Muslims would be as great as those between Muslims and Han Chinese. Most local residents believe that independence would lead to significant conflicts between these groups, along ethnic, religious, urban-rural, and territorial lines. Given the harsh climate and poor resources in the region, those caught in the middle would have few places to flee. Xinjiang Han would naturally seek to return to the interior of China, since Russia and Mongolia would be in no position to receive them. Yet given the premise that only a complete collapse of the state could precipitate a viable independence movement and internal civil war in Xinjiang, there would be few places the Han would be able to go. Certainly, the bordering provinces of Gansu and Qinghai would be just as disrupted, and Tibet would not be an option. Uyghur refugees would most likely seek to move south, since the north would be dominated by the Han and the western routes would be closed off by Kazakhstan and Kyrgystan. That leaves only the southern routes, and with the exception of Pakistan, no nation in the region would probably be equipped to receive them. Certainly, they would not be better off in present-day Tajikistan and Afghanistan. Given the on-going conflicts in Kashmir, even Pakistan, the most likely recipient of Uyghur refugees, would probably not wish further destabilization of the region. Note also that the main southern route to India and Pakistan, along the Karakhorum highway through the Torghurat pass, is generally passable less than six months out of the year. India, despite its poor relations with China, would certainly not want to add to its Muslim population. During many conversations 
in Xinjiang with local residents, Muslim and Han alike, it became clear that this fact is well-known. Most think that in such a worst-case scenario, there would be nothing to do but stay and fight.

Clearly, China needs a new approach to resolve tensions in Xinjiang; purely Marxist and Keynesian economic development strategies are not enough. The "Develop the West" campaign described by Weimer has slowed considerably since September 11, and tourism has slowed dramatically in the region. The state's economic investment plan has proven not to be a panacea for resolving on-going ethnic and problems in the region, that are based on more than just poverty. In a July-August 2002 Foreign Affairs article, Chien-Peng Chung of the Singaporean Institute of Defense and Strategic Studies, called for an immediate political changes in the region to avoid further deterioration in ethnic relations. ${ }^{37}$ To further this discussion, I would like to suggest possible new models for Xinjiang's future, peaceful development, something that all Uyghurs and Chinese, as well as the other 24 ethnic groups in the region, seem to want.

$\checkmark$ The Alaska model: Award residents of Xinjiang direct dividends for returns on wealth derived from regional natural resources, in accord with Article Two of the International Covenant on Economic, Social, and Cultural Rights mentioned above. By according benefits to all $2^{\text {nd }}$ or $3^{\text {rd }}$ generation residents of Xinjiang, China can perhaps obviate inter-ethnic tensions in the region and deflect criticisms that recent non-local migrants "lured to the region" by a government interested in integration through immigration are the real beneficiaries of China's increased investment of the region.

o The Scotland model: Although it is clear China would never consider granting full independence to the region (lest it lose its authority over Tibet and Taiwan as well), an approach that grants the region more control over its own resources and governance, while maintaining central control over national defense and international trade would not only seem to make sense in the modern era, but parallels traditional models of Chinese imperial control of the region under the last dynasty.

o The Hawai'i model: China must find a way to allow its local peoples to legally, democratically, and officially express their concerns about the development process in the region, the future directions of tourism and trade, and the prospects for greater autonomy and sovereignty. In the state of Hawai'i, elected members of the Office of Hawaiian Affairs (OHA) receive state and federal

${ }^{37}$ Chien-Peng Chung “China's War on Terror': September 11 and Uighur Separatism” Foreign Affairs July/ August 2002: 8 . 
funding for gathering input from indigenous Hawaiian peoples and determining the future of Hawaiian sovereignty initiatives, allowing for open and public debate about the real possibilities for independence, nationhood, further autonomy, and the future of Hawaiian lands.

$\checkmark$ The Australia model: Peoples regarded by themselves and international organizations as aboriginal and indigenous must have the right to address land and environmental rights issues, despite government disagreements about historical migration to the region. As yet, China's extremely beneficial special entitlement laws for the official minority nationalities, including nationwide bilingual education, exemption from many taxes and birth-planning restrictions, and educational advancement opportunities apply only to those regarded by the state as designated official minorities, and not to those regarded as indigenous to a region or district (Korean migrants to Xinjiang have as many rights as Uyghur). China has no laws pertaining to indigenous rights, and often regards treaties relating to "peoples" as affecting all the peoples of China, including the Han majority, when their original intent was to alleviate suffering of underprivileged indigenes.

$\checkmark$ The West Bank model? International observers and frequent visitors to the region are concerned that if China does not explore other options besides repression, restriction, and investment, millions of Uyghur Muslims might become increasingly marginalized and disenfranchised, encouraging some of the more disgruntled among them to look to the Intifada, the Taliban, or the al Qaida for inspiration. This would not be in China's or the West's interest in the region, both of which publicly support goals of stability, prosperity, and human rights.

China is a sovereign state, and like all modern nations in the era of globalization faces tremendous challenges from migration, economic imbalance, ethnic unrest, and cyber-separatism. Clearly, the Xinjiang model must be as unique to the region as the region is to China itself. Not unlike Hong Kong (which under the one country, two systems formulae continues to fly its own flag), and many proposals for Taiwan integration, the unique situation in Xinjiang, and possibly Tibet, calls for dramatic and creative solutions to local opposition in the region documented in this paper. The future of this vastly important region, which Owen Lattimore once called the "pivot of Asia," depends upon it.

In the past 10 years, the opening of China to the outside world has meant much for the Uyghur who may easily travel beyond China's borders through Pakistan along the Karakhoram highway, through the Ili valley into Kazakhstan, or by several CAAC flights to Istanbul from Urumqi. The number of Uyghur 
pilgrims travelling on the Hajj to Mecca has increased by 300 per cent. These contacts have allowed the Uyghur to see themselves as participants in the broader Islamic Umma, while at the same time being Muslim citizens of the Chinese nation-state. As they return from the Hajj, many Uyghur who generally travel together as a group have told me that they gained a greater sense of affinity with their own as one people than with the other multi-ethnic members of the international Islamic community. State promoted tourism of foreign Muslims and tourists to Muslim areas in China in hopes of stimulating economic investment is also an important trend related to this opening of Xinjiang and its borders. Urumqi, a largely Han city constructed in the last fifty years, is undergoing an Islamic facelift with the official endorsement of Central Asian and Islamic architecture which serves to impress many visiting foreign Muslim dignitaries. Most foreigners come to see the colourful minorities and the traditional dances and costumes by which their ethnicity is portrayed in Chinese and foreign travel brochures. One Japanese tourist with whom I once spoke in Kashgar, who had just arrived by bicycle from Pakistan across the Karakhorum highway, said that a tourist brochure told him that the real Uyghurs could only be found in Kashgar, whereas most Uyghur believe that Turfan is the centre of their cultural universe. Yet many of these Kashgaris will in the same breath argue that much of traditional Uyghur culture has been lost to Han influence in Turfan and that since they themselves are the repositories of the more unspoiled "Uyghur" traditions, tourists should spend their time, and money, in Kashgar. This search for the socalled "real Uyghur" confirms that the nationality statistics and tourism agencies have succeeded. The re-creation of Uyghur ethnicity has come full circle: the Chinese nation-state has identified a people who have in the last 40 years taken on that assigned identity as their own, and in the process, those who have accepted that identity have sought to define it and exploit it on their own terms. The Uyghur believe they have a 6,000 year cultural and physical history in the region. They are not likely to let it go. Unless new models are explored, patterns of opposition may coalesce to increasingly resist Chinese control and development of the region. 